\title{
EXAMINING \\ THE \\ FINANCIAL \\ DEVELOPMENT-ECONOMIC GROWTH NEXUS FROM AN INSTITUTIONAL APPROACH: EVIDENCE FROM NON-OIL ARAB COUNTRIES
}

\author{
Abdelkarim \\ Yahyaoui $^{1+}$ \\ (D) Kaies Samet ${ }^{2}$ \\ Amina Amirat ${ }^{3}$
}

\author{
${ }^{1,3}$ Department of Finance and Economics, College of Business, University of \\ Jeddah, Saudi Arabia. \\ 'Email:yahyaoui.abdelkarim@yahoo.fr \\ ${ }^{2}$ Department of Economics, High Institute of Industrial Management of Sfax, \\ Tunisia.
}

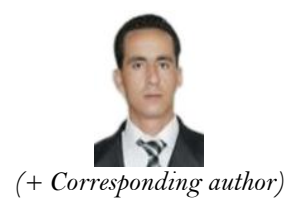

+ Corresponding author
(T) Check for updates

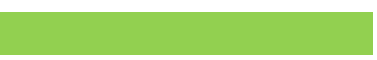

Article History

Received: 2 February 2021 Revised: 19 March 2021

Accepted: 4. May 2021

Published: 31 May 2021

\section{Keywords}

Economic growth

Financial development

Generalized method of moments

Institutional arrangements

Quality of institutions

Arab countries.

\section{JEL Classification:}

$\mathrm{O} 16 ; \mathrm{O} 43 ; \mathrm{O} 47$; $\mathrm{O} 17$; 23 ; $\mathrm{O}_{50}$.
This paper highlights how institution quality plays an important role in the financial development and economic growth nexus in six developing Arab countries. Several estimations were calculated using the generalized method of moments (GMM) covering the period from 1990 to 2016. The results for the selected countries show that the institutions' quality is responsible for diffusion between financial and real spheres. Thus, the financial system needs good institutional quality presented by better socioeconomic conditions, corruption control and a well-respected legal framework to accelerate economic growth.

Contribution/Originality: This study is one of very few studies which have investigated whether institutional reform is necessary for the success of financial reforms, and that the financial system of non-oil Arab countries does not function well unless it is accompanied by intentional good quality. Thus, the relationship between financial development and economic growth in these countries is indirect and requires the establishment of high-quality institutions.

\section{INTRODUCTION}

Economists use several factors to describe the discrepancies in the stages of economic growth between countries. These factors include the geographical position, natural reserves, financial expansion, and the quality of institutions. In this context, to stimulate growth, international financial organizations have suggested a mixture of economic and financial improvements as well as institutional modifications that will lead to the achievement of these improvements. In fact, a broad agreement has been established regarding the types of efficient strategies that countries should adhere to in order to develop their financial systems and stimulate economic and social development (Angelopoulos, Economides, \& Vassilatos, 2011; Blackburn \& Forgues-Puccio, 2010; Holder, 2007; Law \& Habibullah, 2009; Yartey, 2008). However, these improvements and developments are not always reached in weak economies. Likewise, the incorporation of the institutional aspect in the study of development remains 
challenging and it is the outcome of a long process. At this level, in the majority of the theoretical and empirical studies, financial development and institutions emerged separately as fundamental determinants of economic growth. Therefore, in this article we aim to show the complementarity between these two fields of analysis in order to explain the level of economic development for six Arab countries not exporting oil. This innovative line of thinking indicates that the financial system is not operating in a vacuity, but instead presupposes a set of organizations.

The central goal of this research is to determine the different transmission channels through which institutional arrangements determine the intensity and the nature of the relationship between the financial sphere and the real sphere.

In order to address this and to determine which channel of transmission is the most important, the rest of the paper is organized as follows: the literature review in section two summarizes the pat studies; the empirical study in section three outlines the econometric modeling approach; sections four and five define the used data and methodology, respectively; section six contains the results and discusses the findings; and the last section concludes and offers some policy implications.

\section{LITERATURE REVIEW}

\subsection{The Influence of Institutional Quality on Financial Development}

Before the end of twentieth century, nearly all Arab nations had tracked a similar cycle of financial improvements. In the case of an emergency, the impact of this cycle on the advancement of these economies is, by all accounts, changed. Undoubtedly, financial developments are accomplished in certain nations and not in others. This distinction in the after-effects of the changes has incited researchers of the International Monetary Fund (IMF) and the World Bank to focus on finding the sources of dissimilarities among countries. In this context, these researchers stress the nature and quality of institutions of every country as being the significant component that should not be ignored in development models. Consequently, they revealed that the level of growth of the financial systems is impeded by excessive degrees of corruption or weak legal schemes. In the same line of thinking, Chossoudovsky (2004) added that accomplishment of each financial reform is linked to the foundation of a robust institutional context described by a legal system, strictly, constraining fraud (Chinn \& Ito, 2006; Demetriades \& Andrianova, 2004).

Baltagi, Demetriades, \& Law (2007) affirm that financial changes, without suitable foundations and of elevated caliber, have been viewed as reasons for financial crises. Authors examined the Asian countries because they launched a reform of their economic strategies before reviewing their institutional policies. Also, Mersch (2005) offered conditions of the liberalization of capital account and showed that "the quality and stability of the legal, institutional, and policy frameworks are essential aspects of economic development. All these elements participate, indeed, to the establishment of good governance and therefore represent a condition for the success of the liberalization of capital movements. The problems of corruption and collusion are barriers to investment and do not allow an efficient allocation of resources". Thus, the success or failure intensity of any change relies on the institutional improvement with the paired political changes executed by countries. Along these lines, nations that do not have a good institutional climate ensuring the privileges of property, or potentially the utilization of the agreements within the entertainers of a financial arrangement, for the most part have inadequately evolved financial frameworks (Law \& Demetriades, 2006).

As indicated by the study of the New Institutional Economics (NIE), when building up the financial system we rely on the political and institutional components. This innovative line of reasoning reveals that the financial system is not working in a vacuity but assumes a set of foundations. These institutions are liable for observing transparency in the market of governmental actions and in the country's effectiveness. Thus, the amelioration of the governmental institutions would have a valuable double effect. First, it would decrease transaction expenses and it 
improve the climate for business (Coase, 1937; Williamson, 1985). Second, it would generate steady policies, which are important to the success of new investment projects financed by a growth-buoyant financial system (North, 1990). Theoretically, the NIE reveals that efficient institutions have a significant impact on the achievement of the financial and economic changes and even presumes that institutions are the essential elements for long-run economic and social development (Chtourou, 2004).

The institutional development of financial systems is facing challenges in the developments that appear in transitional economies. Even though the research that focuses on these issues, specialists in institutional economics concentrate more on the development of the institutions in general, while experts in financial economics only analyze the financial markets. However, Levine (1997) clarifies the existence of liaisons between institutions and financial markets. Hence, he uses the term "third type" factors to refer to institutions. These institutions must adhere to a specific structure to guarantee the success of any financial system reforms. After the work of Levine (1997), several studies tried to analyze the importance of the relationship between institutions and financial systems. Pistor, Raiser, \& Gelfer (2000) found that the development of the financial market relies on the existence of a good institutional structure in the case of countries in transition, but they did not detect any causal relationship between them.

One suggested explanation for the incapability of studies to show the relationship between institutions and financial systems is the divergent definitions of these terms. However, before the end of the 1990s, there was a recharged interest to clarify financial globalization, the reasons for financial crisis, and the expenses and advantages of financial liberalization (Kaminsky \& Schmukler, 2002). To guarantee that financial systems can benefit from the advantages of financial liberalization, the financial frameworks themselves must be improved by the foundation of a strong institutional structure (Martell \& Stulz, 2003). Likewise, LLSV (1997); LaPorta, Lopez-de-Silanes, Shleifer, and Vishny (1997) and Beck \& Levine (2004) analyzed the cases of countries with weak and emerging capital markets, especially those following French civil law. They found that the growth of financial markets needs the existence of regulations to protect the rights of shareholders. Law \& Azman-Saini (2008) and Law \& Azman-Saini (2012) revealed that as countries strengthen and consolidate their institutional infrastructures, they will stimulate the development of financial systems.

Law \& Azman-Saini (2008) reached the same conclusion as LaPorta et al. (1997) and Lombardo \& Pagano (2000) regarding the quality of institutions and its positive impact on the development of financial systems. LaPorta et al. (1997) found that the functioning of the financial markets in transitioning economies needs the existence of legal institutions. Lombardo \& Pagano (2000) studied the relation between the quality of institutional environment and return on equity. They detected that the quality of legal institutions is positively correlated with adjusted return on equity. The origin of the legal system, the compliance with the law and the absence of corruption were the main elements used to assess the quality of legal institutions.

Hooper, Sim, \& Uppal (2009) analyzed the relationship between the performance of financial systems and the quality of institutions using an international financial asset valuation model. They demonstrated that the fair operation of the judicial systems, the level of political steadiness, and the degree of systemic corruption characterize the quality of institutions and their capability of monitoring financial markets. Chinn \& Ito (2006) revealed that corruption has a negative impact on the development of financial systems. Therefore, if developing countries want to benefit as much as possible from financial reforms, they need a sophisticated legal and institutional environment, especially in the banking sector. Several factors must characterize the laws and regulations in banking sectors, such as creditor protection, and the degree of reliability and transparency to which they must operate. If countries lack a legal system where property rights are clearly defined and the guarantees for contracts are absent, the motivations for lending may be limited (LLSV, 1997; LaPorta et al., 1997). LLSV (1997) explained the disparities in the degrees of financial development between countries by the level of development of their legal systems and corruption. Likewise, Claessens, Djankov, Fan, \& Lang (2002); Claessens \& Laeven (2003) and Caprio, Laeven, \& Levine (2007) 
demonstrated that any rise in the efficacy of the legal structure and the legal safety of the creditors leads to the development of financial systems. Thus, the development of financial systems is strongly linked to a solid institutional framework.

\subsection{Role of Institutional Quality in the Finance-Growth Relationship}

In recent years, the value of institutional factors in the development of financial systems has become evident (Hasan, Wachtel, \& Zhou, 2009; Kutan, Samargandi, \& Sohag, 2017; Law \& Habibullah, 2006; Law \& Azman-Saini, 2012; Minea \& Villieu, 2010; Wang, Cheng, Wang, \& Li, 2014; Weill, 2011). Consequently, these factors can help to implement policies targeting institutional reforms which are needed to promote growth-enhancing financial systems (Berhane, 2018; Blackburn \& Forgues-Puccio, 2010; Casson, Giusta, \& Kambhampati, 2010; Kaidi, Mensi, \& Amor, 2019; Khan, Khan, Abdulahi, Liaqat, \& Shah, 2019).

A large portion of studies connecting institutions, finance, and development has only focused on the relation between the fields of governance and financial development, i.e., economic growth. At this stage, LLSV (1997) used the legal side to interpret the disparity in the degrees of financial development between countries. These studies show the importance of institutional factors in the definition of financial development. Ahlin (2005) continued along the same line as LLSV and demonstrated the non-linearity of the relation between financial development, growth, and corruption. They showed that the role of financial development in economic growth can be inhibited by high levels of corruption; the same conclusion was confirmed by the work of Kunieda, Okada, \& Shibata (2016). Other works, such as Keefer \& Knack (1997) and Aghion, Howitt, \& Mayer-Foulkes (2005), revealed that the misfunctioning of financial systems is due to corruption. The main conclusion of these papers is that economic growth needs a well-developed financial system and that this can be reached by creating an adequate legal environment and decreasing the level of corruption. But no study has included both financial and institutional development in the same growth model and does not clarify how a healthy institutional context reinforces the finance and growth relationship.

Djankov, McLiesh, \& Shleifer (2007) examined a sample of 129 countries and found that creditor protection is correlated with greater ratios of private credit to gross domestic product (GDP). Few studies have dealt with the relationship between financial development and economic growth in the institutional framework and they did not reach clear conclusions. One of these, a study by Arestis \& Demetriades (1997), clarified that financial expansion of a country fosters growth and relies mainly on its regulatory context. Claessens \& Laeven (2003) demonstrated that giving protection to investors and creditors will enhance their confidence in the financial system and will also stimulate economic growth through the development of the financial system. Likewise, Pissarides, Singer, \& Svejnar (2003) and Beck, Demirgüç-Kunt, \& Maksimovic (2005) revealed that high levels of corruption will disable a financial system's ability to push growth. This validates the suggestion of Brunetti, Kisunko, \& Weder (1999), who detected that a decrease in corruption encourages financial development.

Demetriades \& Hook-Law (2006) analyzed a sample of 72 countries from 1978 to 2000 and found that the existence of powerful institutional context will enhance the impact of financial development on GDP per capita, though the effect of financial development on economic growth remains the same in both strong and weak countries, even with the existence of a healthful institutional atmosphere.

Andrianova, Demetriades, \& Shortland (2008) revealed that the institutional context incorporates the deft conduct of the banks, specifically the prudential guidelines and management, the implementation of agreements, and the standard of legislation. The authors added that the nature of organizations assumes a central function in the assurance of the property rights of the depositors and they have also proved that the bad quality of an institution and the excessive percentage of speculators will discourage the launch of new private banks. The existence of private banks raises the competitiveness between banks and leads to the diversification of financial products. Andrianova et al. (2008) investigated the impact of laws and regulations in the functioning of the banking sector in 
supporting development and the authors declared that if governments want to establish a strong system of laws and regulations, they need compliance from all engaging parties related to property rights and contracts. This means that the expenses of external financing will be reduced due to the decrease in the fees related to collecting information on corporations. Hasan et al. (2009) and Angelopoulos et al. (2011) indicated that financial market expansion, the legal atmosphere, property rights perception and political diversity are linked to stronger growth.

Law \& Azman-Saini (2012) examined the impact of institutions' quality on financial growth in a sample containing both developing and developed countries. They demonstrated that institutional quality has an impact on financial development which differs from one country to another, and this impact is non-monotonic according to the degree of economic expansion. Hence, the characteristics of the institutions and of the legal context must be well developed in poor countries to promote financial development (Berhane, 2018; Kaidi et al., 2019; Khan et al., 2019; Kutan et al., 2017).

\section{MODEL SPECIFICATION}

In this section, we examine the impact of institutional quality on the relationship between finance and growth. The study was performed on six Arab countries over the period from 1990 to 2016, and we referred to the research of Mankiw, Romer, \& Weil (1992) to select an appropriate model. The model to be estimated with delay in endogenous variables is as follows:

$$
\begin{gathered}
\ln G D P_{i t}=\alpha_{i} \ln G D P_{i t-1}+\beta_{1 i} \ln k_{i t}+\beta_{2 i} \ln \square_{i t}+\beta_{3 i} \ln l f_{i t}+\beta_{4 i} F D_{i t}+\beta_{5 i}\left(I N S_{i t} * F D_{i t}\right)+\mu_{i} \\
\quad+\varepsilon_{i t}(1)
\end{gathered}
$$

where GDP is real GDP per capita, $\mu_{i}$ is the individual effect, $L n k$ is physical capital stock, $L n h$ is human capital stock, Lnlf is the growth rate of the labor force, $F D$ is financial development, INS is the quality of institutions, $I N S \times F D$ is the interaction term, $\varepsilon_{i t}$ is the idiosyncratic error term with $E\left(\varepsilon_{i t}\right)=0$, and $\beta^{\mathrm{F}}=\left(\alpha_{,} \beta_{1}, \beta_{2}, \beta_{3}, \beta_{4}, \beta_{5}\right)$ is the vector estimate of the coefficients.

The measure of GDP can be dynamic in nature and the econometric analyses of the dynamic nature of GDP measure involves lagged values of GDP as an explanatory variable:

$$
y_{i t}=\alpha y_{i t-1}+\beta x_{i t}+\vartheta_{i t} \mathrm{i}=1, \ldots \ldots \ldots, N t=2, \ldots \ldots \ldots \ldots . T
$$

where $\delta$ is a scalar, $x_{i t}$ is $1 \times 5$ vector of explanatory variables, and $\beta$ is a $5 x 1$ vector of parameters to be estimated.

The error term $\vartheta_{i t}$ is composed of an unobserved effect and a time-invariant effect as shown below:

$\vartheta_{i t}=\mu_{i}+\varepsilon_{i t}(3)$

where $\mu_{i} \sim I I D\left(0, \sigma_{\mu}^{2}\right)$ and $\varepsilon_{i} \sim I I D\left(0, \sigma_{s}^{2}\right)$ are independent of each other. The dynamic panel data regressions described in Equations 2 and 3 are characterized by two sources of persistence over time, i.e., autocorrelation because of the existence of a lagged dependent variable $\mathrm{y}_{\mathrm{i}, \mathrm{t}-1}$ among the regressors, and individual effects characterizing the heterogeneity among the individuals $\mu_{i}$. 


\section{DATA AND SOURCES}

Our data sample includes six developing non-oil Arab countries (Lebanon, Tunisia, Syria, Morocco, Jordan and Egypt $)^{1}$ from 1990 to 2016. These countries were selected based on their World Bank ranking taking into consideration their levels of economic development and the harmony within the sample.

The variables included in this paper are real gross domestic product per capita as an endogenous variable, growth rate of the labor force, physical capital stock per capita, human capital stock per capita ${ }^{2}$, three indicators related to financial development ${ }^{3}$, and five indicators of governance and institutional quality.

We have calculated the physical capital stock by employing the perpetual inventory method described by Van Pottelsberghe De la Potterie (1997). Based on the work of Mankiw et al. (1992), we have used the secondary schooling growth rate as a proxy of human capital.

The expressions "national governance" and "good governance" emerged in the middle of the 1990s in the World Bank's jargon. Kaufmann, Kraay, \& Mastruzzi (2008) identified governance as "the traditions and institutions by which authority is exercised in a country for the common good. This includes the processes by which governments are selected, controlled and replaced, the government's ability to develop and implement solid policies, and the respect of citizens and the state for the institutions governing their economic and social interactions". This description involves numerous facets of governance as the democratic quality of political organizations, political instability and violence, the efficiency of the public authorities, the power of the regulations, the rule of law, and the fight against corruption. In this paper, we adopted the above definition because it includes the nature of the regimes.

Referring to the above definition, this study includes four indicators of institution ${ }^{4}$, namely corruption (COR) reflecting the nature of the political regime, the socio-economic conditions (SEC) reflecting the efficiency of the government, law and order (LO), and bureaucratic quality (BQ) to represent the respect of the institutions. These indicators were obtained from the database of the Political Risk Services (PRS) Group ${ }^{5}$, as these annual variables of the International Country Risk Guide (ICRG) are products of the PRS Group. The corruption, socio-economic conditions, and law and order variables range from 0 to 6 , whereas bureaucratic quality ranges from 0 to 4 . As a rule, higher values indicate better scores, i.e., less corruption means better socio-economic condition, a more effective legal system and better bureaucracy. These variables follow the same scores and for this reason we modified the scale, thus the annotation of variables range from 0 to 10 with the greatest values indicating better institutional quality.

\section{METHODOLOGY}

In this paper, we employed the generalized method of moments (GMM) estimator of Arellano Bover/BlundellBond. It considers the existence of unseen country-specific effects and any potential bias of omitted variables that are constant over time.

To deal with the problem of endogeneity in this analysis, we employed the GMM technique, thus taking the first difference GMM estimator proposed by Arellano \& Bond (1991) and the GMM system estimator of Blundell \&

\footnotetext{
${ }^{1}$ We have selected the Arab countries with comparable economic development, and have excluded countries where the export of hydrocarbons is the primary source of wealth. The choice of this group of countries proved to be important in overcoming the problem of heterogeneity between countries for our representative sample.

2 The real GDP per capita, labor force and financial development variables were extracted from the basic indicators of data from the World Bank.

${ }^{3}$ The financial development indicators are the liquidity rate, credit to the private sector, and domestic credit provided by the banking sector. All these indicators, which are ratios to GDP, were extracted from the basic indicators of data from World Bank Indicators and website https://www.indexmundi.com/facts/indicators/FS.AST.PRVT.GD.ZS/compare?country=tn
}

${ }^{4}$ These variables are the most applied in the works linking finance to growth (see Beck, Levine, \& Loayza (2000)).

${ }_{5}^{5}$ The PRS Group provides annual estimates on the quality of institutions for the period 1984-2018. 
Bond (1998). The GMM system technique of Blundell \& Bond $(1998)^{6}$ has the advantage of allowing the correction of endogeneity regardless of its origins. Moreover, the GMM system method makes it possible to correct the endogeneity of the explanatory variables of interest, as well as the other explanatory variables that are susceptible to endogeneity, provided that an adequate number of lagged variables are used as instruments.

The GMM stipulates the orthogonality conditions between the lagged variables and the error term, both in terms of first difference and in level. When the dynamic model is expressed in first difference, the instruments are level, and vice versa. In the model to be assessed, the use of lagged variables as instruments varies according to the nature of the explanatory variables ${ }^{7}$. The authenticity of the instruments kept can be validated, or not, according to the tests of Hansen and Sargan.

The first difference GMM estimator of Arellano \& Bond (1991) involves using the first difference of the equation to be estimated for each period and the removal of the individual specific effects. Thus, we get:

$\Delta y_{i t}=\alpha \Delta y_{i t-1}+\beta \Delta X_{i t}+\Delta \varepsilon_{i t}$.

It is then a question of instrumentalizing the lagged endogenous variable by its past values of four periods or more ${ }^{8}$. However, this method does not allow the identification of the effects of invariant factors over time.

The GMM system estimator proposed by Blundell \& Bond (1998) combines the first difference equations with equations in level. The instruments in the first difference equation are expressed in level and vice versa.

$\left\{\begin{array}{l}\Delta y_{i t}=\alpha \Delta y_{i t-1}+\beta \Delta X_{i t}+\Delta \varepsilon_{i t} \\ y_{i t}=\alpha y_{i t-1}+\beta x_{i t}+\mu_{i}+\varepsilon_{i t}\end{array}\right.$

\section{RESULTS AND DISCUSSIONS}

We applied the GMM system for six developing Arab countries from 1990 to 2016. The results are summarized in the tables below. Tables 1, 2 and 3 recapitulate the estimations for the four institutional variables mentioned above (COR, SEC, LO and BQ), the three indicators of financial development ${ }^{9}$, and the control variables in the different models. We have included, when conceivable, one of the four indicators of institutions from the ICRG database.

In the first table, financial development is assessed by the "liquid liabilities (M3) as \% of GDP" (LL) variable, that measures the level of liquidity in the financial system. The table shows the five regressions that were demonstrated to compare the direct to the indirect effects of financial development on GDP per capita.

The estimation findings displayed in Table 1 are of high importance as they validate the significant relationship that financial development has with a solid institutional environment and GDP per capita. Table 1 also shows a regression giving only financial development (regression 1). Hence, the direct impact of financial development on GDP per capita was examined in this regression, though in regressions 2 to 5 we incorporated the financial variable networking with the four indicators of institution. We found that when we incorporated the institutional variables of the ICRG interacting with the "liquid liabilities (M3) as \% of GDP" (LL) financial variable, the financial development effects on GDP per capita increased, especially at the significance level. The significance levels

${ }^{6}$ Blundell and Bond (1998) have shown through the recurrence of Monte Carlo simulations that the GMM system estimator is more efficient than the first difference GMM estimator, since the latter gives biased results in finite samples when the instruments are weak.

${ }^{7}$ For exogenous variables, their current values were used as instruments. For predetermined or weakly exogenous variables, their lagged values of at least one period can be used as instruments. For endogenous variables, their lagged values of two or more periods can be valid instruments.

${ }^{8}$ According to the tests of the validity of instruments of Hansen and Sargan.

${ }^{9}$ Financial development is measured by the liquidity rate of the financial system (LL) for Table 1, domestic credit to the private sector (DCPS) for Table 2 , and domestic credit provided by the banking sector (DCBS) for Table 3 . 
switched from 0.003 to 0.009 when the indicators of socioeconomic conditions (SEC) and law and order (LO) were included, then to 0.041 when bureaucratic quality (BQ) was included, and to -0.001 when corruption (COR) was included.

Table 1. Effects of the LL through the features of institution on GDP per capita.

\begin{tabular}{|c|c|c|c|c|c|}
\hline & $\mathbf{R} 1$ & R 2 & R 3 & R 4 & R 5 \\
\hline Constant & $\begin{array}{c}2.110 \\
(4.122)^{* * * *}\end{array}$ & $\begin{array}{c}2.108 \\
(4.221)^{* * * *}\end{array}$ & $\begin{array}{c}4.22 \\
(5.060)^{* * * *} \\
\end{array}$ & $\begin{array}{c}4.02 \\
(5.22)^{* * *} \\
\end{array}$ & $\begin{array}{c}4.128 \\
(5.17)^{* * * *}\end{array}$ \\
\hline LAG-GDP & $\begin{array}{c}0.066 \\
(0.3001)\end{array}$ & $\begin{array}{l}0.002 \\
(0.88)\end{array}$ & $\begin{array}{c}0.011 \\
(0.873)\end{array}$ & $\begin{array}{c}-0.114 \\
(-0.771)\end{array}$ & $\begin{array}{c}0.026 \\
(0.129)\end{array}$ \\
\hline $\operatorname{lnk}$ & $\begin{array}{c}0.520 \\
(3.016)^{* * * *}\end{array}$ & $\begin{array}{c}0.002 \\
(4.126)^{* * *} *\end{array}$ & $\begin{array}{c}0.201 \\
(3.022)^{* * * *}\end{array}$ & $\begin{array}{c}0.096 \\
(2.448)^{* * * *}\end{array}$ & $\begin{array}{c}0.081 \\
(2.508)^{* * * *}\end{array}$ \\
\hline $\operatorname{lnh}$ & $\begin{array}{c}0.332 \\
(2.314)^{* * * *} \\
\end{array}$ & $\begin{array}{c}0.713 \\
(5.006)^{* * * *} \\
\end{array}$ & $\begin{array}{c}0.125 \\
(2.311)^{* * * *} \\
\end{array}$ & $\begin{array}{c}0.87 \\
(2.065)^{* * * *} \\
\end{array}$ & $\begin{array}{c}0.119 \\
(2.43)^{* * * *} \\
\end{array}$ \\
\hline $\operatorname{lnlf}$ & $\begin{array}{c}-0.022 \\
(-4.051)^{* * * *}\end{array}$ & $\begin{array}{c}-0.002 \\
(-2.88)^{* *}\end{array}$ & $\begin{array}{c}-0.019 \\
(-2.13)^{* *}\end{array}$ & $\begin{array}{c}-0.001 \\
(-2.19)^{* * * *}\end{array}$ & $\begin{array}{c}-0.011 \\
(-2.86)^{* * * *}\end{array}$ \\
\hline LL & $\begin{array}{c}0.003 \\
(4.110)^{* * * *}\end{array}$ & & & & \\
\hline LL*COR & & $\begin{array}{c}-0.001 \\
(-2.24)^{* * * *}\end{array}$ & & & \\
\hline LL*SEC & & & $\begin{array}{c}0.009 \\
(6.826)^{* * * *}\end{array}$ & & \\
\hline LL*LO & & & & $\begin{array}{c}0.009 \\
(5.022)^{* * * *} \\
\end{array}$ & \\
\hline $\mathrm{LL} * \mathrm{BQ}$ & & & & & $\begin{array}{c}0.041 \\
(3.896)^{* * * *}\end{array}$ \\
\hline Sargan test (p-value) & 0.390 & 0.229 & 0.243 & 0.476 & 0.485 \\
\hline $\mathrm{P}$-value $\operatorname{AR}(1)$ & 0.04 & 0.032 & 0.027 & 0.001 & 0.022 \\
\hline $\mathrm{P}$-value $\operatorname{AR}(2)$ & 0.402 & 0.565 & 0.239 & 0.766 & 0.376 \\
\hline Hansen test (p-value) & 0.274 & 0.324 & 0.335 & 0.621 & 0.351 \\
\hline
\end{tabular}

In the second table, financial development was assessed by the "domestic credit to private sector (\% of GDP)" (DCPS) variable. The most significant amelioration was obtained using variables measuring law and order (LO) (regression 9), in which significance shifts from 0.001 to 0.007 . This output validates the vital role of the quality of the legal system. Likewise, the positive effect of financial development on growth becomes negative by the presence of a corrupt environment. The coefficient changed from 0.001 to -0.002 , indicating that the favorable effect of financial development is mitigated by the presence of corruption. In the third table, financial development is assessed by the "domestic credit provided by the banking sector (\% of GDP)" (DCBS) variable. In this table, five models are exhibited to compare the direct and indirect effects of financial development on GDP per capita. The best improvement was found using variables measuring law and order (LO) (regression 14). This finding reinforces the importance of having a high-quality legal system and shows the power and objectivity of the justice system and the conformity with the banking sector's regulations. We confirmed the findings of Modigliani \& Perotti (2000), which revealed the value of quality when applying legal rules as a key for financial development and economic growth. In the three preceding tables, the results of the Sargan-Hansen test in the GMM system show that the lagged variables of the different endogenous variables are good instruments. The results found in regressions R4, R9 and R14 are consistent with those found in the other regressions, both at the coefficient and significance levels. Our findings uphold the fact that a solid institutional climate is important for the expansion of financial systems and the incitement of economic growth in the Arab nations. The reinforcement of the financial systems by building good governance empowers these nations to develop their economic conditions. 
Table 2. Effects of the DCPS through the features of institution on GDP per capita.

\begin{tabular}{|c|c|c|c|c|c|}
\hline & R 6 & $\mathbf{R} 7$ & $\mathbf{R ~} 8$ & $\mathbf{R ~} 9$ & R 10 \\
\hline Constant & $\begin{array}{c}5.001 \\
(4.046)^{* * * * *}\end{array}$ & $\begin{array}{c}4.958 \\
(3.858)^{* * * *}\end{array}$ & $\begin{array}{c}4.416 \\
(4.975)^{* * * * *}\end{array}$ & $\begin{array}{c}5.201 \\
(4.288)^{* * * *}\end{array}$ & $\begin{array}{c}4.881 \\
(4.902)^{* * * *}\end{array}$ \\
\hline LAG-GDP & $\begin{array}{c}-0.011 \\
(-0.341)\end{array}$ & $\begin{array}{c}0.002 \\
(0.761)\end{array}$ & $\begin{array}{c}0.003 \\
(0.831)\end{array}$ & $\begin{array}{c}-0.082 \\
(-0.906)\end{array}$ & $\begin{array}{c}0.060 \\
(0.363)\end{array}$ \\
\hline $\operatorname{lnk}$ & $\begin{array}{c}0.053 \\
(2.064)^{* * * * *}\end{array}$ & $\begin{array}{c}0.022 \\
(2.620)^{* * * *}\end{array}$ & $\begin{array}{c}0.046 \\
(2.025)^{* * * * *}\end{array}$ & $\begin{array}{c}0.044 \\
(2.249)^{* * * *}\end{array}$ & $\begin{array}{c}0.046 \\
(2.461)^{* * * *}\end{array}$ \\
\hline $\operatorname{lnh}$ & $\begin{array}{c}0.280 \\
(2.511)^{* * * * *}\end{array}$ & $\begin{array}{c}0.598 \\
(4.411)^{* * * *}\end{array}$ & $\begin{array}{c}0.622 \\
(2.108)^{* * * *}\end{array}$ & $\begin{array}{c}0.422 \\
(3.31)^{* * * *}\end{array}$ & $\begin{array}{c}0.667 \\
(3.772)^{\text {****** }}\end{array}$ \\
\hline $\operatorname{lnlf}$ & $\begin{array}{c}-0.122 \\
(-1.948)^{*}\end{array}$ & $\begin{array}{c}-0.022 \\
(-2.005)^{*}\end{array}$ & $\begin{array}{c}-0.011 \\
(-2.25)^{* * * *}\end{array}$ & $\begin{array}{c}-0.015 \\
(2.466)^{* * * *}\end{array}$ & $\begin{array}{c}-0.011 \\
(-3.29)^{* * * *}\end{array}$ \\
\hline DCPS & $\begin{array}{c}0.001 \\
(2.79)^{* * * *}\end{array}$ & & & & \\
\hline DCPS*COR & & $\begin{array}{c}-0.002 \\
(-3.44)^{* * * *} \\
\end{array}$ & & & \\
\hline DCPS*SEC & & & $\begin{array}{c}0.002 \\
(3.581)^{* * * *}\end{array}$ & & \\
\hline DCPS*LO & & & & $\begin{array}{c}0.007 \\
(4.662)^{* * * *}\end{array}$ & \\
\hline $\mathrm{DCPS} * \mathrm{BQ}$ & & & & & $\begin{array}{c}0.008 \\
(2.792)^{* * * * *}\end{array}$ \\
\hline Sargan test (p-value) & 0.265 & 0.252 & 0.221 & 0.576 & 0.482 \\
\hline P-value $\mathrm{AR}(1)$ & 0.001 & 0.018 & 0.011 & 0.008 & 0.014 \\
\hline $\mathrm{P}$-value $\operatorname{AR}(2)$ & 0.452 & 0.308 & 0.363 & 0.522 & 0.381 \\
\hline Hansen test (p-value) & 0.418 & 0.482 & 0.344 & 0.585 & 0.322 \\
\hline
\end{tabular}

Table 3. Effects of the DCBS through the features of institution on GDP per capita.

\begin{tabular}{|c|c|c|c|c|c|}
\hline & R 11 & R12 & R13 & R14 & R 15 \\
\hline Constant & $\begin{array}{c}4.272 \\
(4.236)^{* * *}\end{array}$ & $\begin{array}{c}4.096 \\
(5.002)^{* * *}\end{array}$ & $\begin{array}{c}4.130 \\
(4.524)^{* * * *}\end{array}$ & $\begin{array}{c}5.502 \\
(4.512)^{* * * *}\end{array}$ & $\begin{array}{c}4.298 \\
(5.253)^{* * * *}\end{array}$ \\
\hline LAG-GDP & $\begin{array}{c}0.002 \\
(0.295)\end{array}$ & $\begin{array}{c}0.002 \\
(0.387)\end{array}$ & $\begin{array}{l}0.011 \\
(0.22)\end{array}$ & $\begin{array}{c}-0.001 \\
(-1.633)\end{array}$ & $\begin{array}{c}0.004 \\
(0.407)\end{array}$ \\
\hline $\operatorname{lnk}$ & $\begin{array}{c}0.044 \\
(3.373)^{* * *}\end{array}$ & $\begin{array}{c}0.041 \\
(3.661)^{* * * *}\end{array}$ & $\begin{array}{c}0.014 \\
(2.451)^{* * *}\end{array}$ & $\begin{array}{c}0.022 \\
(2.802)^{* * *}\end{array}$ & $\begin{array}{c}0.031 \\
(2.407)^{* * *}\end{array}$ \\
\hline $\operatorname{lnh}$ & $\begin{array}{c}0.299 \\
(2.522)^{* * *}\end{array}$ & $\begin{array}{c}0.237 \\
(2.422)^{* * *}\end{array}$ & $\begin{array}{c}0.0 .385 \\
(3.095)^{* * *}\end{array}$ & $\begin{array}{c}0.309 \\
(2.530)^{* * * *}\end{array}$ & $\begin{array}{c}0.561 \\
(2.898)^{* * *}\end{array}$ \\
\hline $\operatorname{lnlf}$ & $\begin{array}{l}-0.011 \\
(-1.77)\end{array}$ & $\begin{array}{c}-0.021 \\
(-2.37)^{* * *}\end{array}$ & $\begin{array}{c}-0.019 \\
(-2.25)^{* * *}\end{array}$ & $\begin{array}{c}-0.013 \\
(-2.20)^{* *}\end{array}$ & $\begin{array}{c}-0.011 \\
(-3.17)^{* * *}\end{array}$ \\
\hline DCBS & $\begin{array}{c}0.004 \\
(4.432)^{*} * *\end{array}$ & & & & \\
\hline DCBS*COR & & $\begin{array}{c}-0.003 \\
(-3.98)^{* * * *} \\
\end{array}$ & & & \\
\hline DCBS*SEC & & & $\begin{array}{c}0.011 \\
(4.502)^{* * *}\end{array}$ & & \\
\hline DCBS*LO & & & & $\begin{array}{c}0.019 \\
(3.896)^{* * * *}\end{array}$ & \\
\hline $\mathrm{DCBS} * \mathrm{BQ}$ & & & & & $\begin{array}{c}0.007 \\
(3.502)^{* * * *}\end{array}$ \\
\hline Sargan test (p-value) & 0.227 & 0.296 & & \multicolumn{2}{|c|}{0.477} \\
\hline P-value $\operatorname{AR}(1)$ & 0.002 & 0.008 & & \multicolumn{2}{|c|}{0.009} \\
\hline $\mathrm{P}$-value $\operatorname{AR}(2)$ & 0.409 & 0.302 & & \multicolumn{2}{|c|}{0.329} \\
\hline Hansen test (p-value) & 0.432 & 0.685 & & \multicolumn{2}{|c|}{0.218} \\
\hline
\end{tabular}


In summary, the existence of well-developed financial systems improves the utilization of reserves in the best investments, which is advantageous for all beneficiaries and for the economy as a whole. For the countries in our sample, which are characterized by the fact that for banking, or the main providers for investments, the quality of institutions must be improved in order to create a favorable environment. However, the existence of high degrees of corruption coupled with weak legal systems lead to illegal actions and prevents the financial systems from being developed. Therefore, the existence of underdeveloped financial systems hampers the economic growth in these countries. The expansion, the reconstruction and the strengthening of the legal and institutional structures represent important elements to ensure the modernization of banking services. Countries, such as those examined in our study, are characterized by a weak quality of institutional context and poor legal systems with increased corruption. Aghion et al. (2005) demonstrated that high degrees of corruption lead to the misfunctioning of the banks, so the quality of the banking sectors and their transparency should be improved to encourage the implementation of high standards that are accepted at an international level. These standards cover the governance area and also the auditing and the treatment of financial statements. Beck, Demirgüç-Kunt, Laeven, \& Maksimovic (2006) investigated the functioning of the banking sector and focused on the negative impact that corruption has on it. Caprio et al. (2007) concluded that the expansion of the role of financial intermediation needs the existence of rules and regulations that protect borrowers.

\section{CONCLUSION}

During recent decades, an abundance of literature has demonstrated that the relationship between financial development and economic growth is indirect. In this paper, it has been shown that the quality of institutions ensures the transmission from the financial to the real sphere in the case of six Arab countries from 1990 to 2016. Thus, a healthy institutional context is important to develop financial systems by restricting corruption with more effective legal systems and improved bureaucracy. Our key empirical findings indicate that the quality of institutions, in its different aspects, is an important element in the development of financial systems. Thus, the quality of application of the legal rules (measured by the LO indicator) is a factor of financial development, and subsequently of economic growth. Correspondingly, the favorable effects of financial development on the economic development of these countries are mitigated by the presence of a high degree of corruption. Consequently, the financial development of these countries assumes a healthy institutional framework presented by a low level of corruption, a more efficient legal system, favorable socio-economic conditions, and better bureaucracy.

In this framework, our study focused on the fact that the quality of institutions and the concept of good governance that it underlies is the transmission vector from the financial to the real sphere for the sample of six developing Arab countries (Lebanon, Tunisia, Syria, Morocco, Jordan and Egypt). Therefore, we demonstrated throughout the prevailing literature that a healthy institutional context is needed for a well-functioning financial system. This theoretical finding is reinforced empirically by the use of the Solow growth model augmented by human capital, which allowed us to detect important impacts of financial development on economic growth through a healthy institutional context.

We concluded that a good institutional atmosphere ensures the best allocation of savings and funds and contributes to a developed financial system. As a consequence, transaction costs will drop and lead to higher productivity; this decrease in fees itself raises commerce and fosters economic growth. This conclusion conforms with the findings of the NIE creators on this issue (Coase, 1937; North, 1990; Williamson, 1985).

Though institutional quality is considered as a requirement, it is not the only factor to play a part in the development of financial systems in Arab countries. The institutions must be covered by a robust government to efficiently accomplish their development policies. Hence, it is essential to have suitable political institutions to protect economic accomplishments against the abuse and mistakes of leaders. Nowadays, the quality of institutions 
remains a vital element of the development of policies that must be given high priority. Therefore, the public authorities must concentrate on institutional quality because it supports proper functioning of the financial systems by offering a better environment for investors. It affects the execution and/or the consolidation of a strong institutional atmosphere to boost financial development and, consequently, economic growth.

Funding: This study received no specific financial support.

Competing Interests: The authors declare that they have no competing interests.

Acknowledgement: All authors contributed equally to the conception and design of the study.

\section{REFERENCES}

Aghion, P., Howitt, P., \& Mayer-Foulkes, D. (2005). The effect of financial development on convergence: Theory and evidence. The Quarterly Journal of Economics, 120(1), 173-222. Available at: https://doi.org/10.1 162/0033553053327515.

Ahlin, C. (2005). Effects and (in) tractability of decentralized corruption. Working Paper, Department of Economics, Vanderbilt University, December.

Andrianova, S., Demetriades, P., \& Shortland, A. (2008). Government ownership of banks, institutions, and financial development. Journal of Development Economics, 85(1-2), 218-252. Available at: https://doi.org/10.1016/j.jdeveco.2006.08.002.

Angelopoulos, K., Economides, G., \& Vassilatos, V. (2011). Do institutions matter for economic fluctuations? Weak property rights in a business cycle model for Mexico. Review of Economic Dynamics, 14(3), 511-531. Available at: https://doi.org/10.1016/j.red.2010.04.002.

Arellano, M., \& Bond, S. (1991). Some tests of specification for panel data: Monte Carlo evidence and an application to employment equations. The Review of Economic Studies, 58(2), 277-297. Available at: https://doi.org/10.2307/2297968.

Arestis, P., \& Demetriades, P. (1997). Financial development and economic growth: assessing the evidence. The Economic Journal, 107(442), 783-799. Available at: https://doi.org/10.1111/j.1468-0297.1997.tb00043.x.

Baltagi, B., Demetriades, P., \& Law, S. H. (2007). Financial development, openness and institutions: Evidence from panel data. World Economy and Finance Research Programme Working Paper No 22.

Beck, T., Levine, R., \& Loayza, N. (2000). Finance and the sources of growth. Journal of Financial Economics, 58(1-2), 261-300.

Beck, T., \& Levine, R. (2004). Stock markets, banks, and growth: Panel evidence. Journal of Banking \& Finance, 28(3), 423-442. Available at: https://doi.org/10.1016/s0378-4266(02)00408-9.

Beck, T., Demirgüç-Kunt, A., \& Maksimovic, V. (2005). Financial and legal constraints to growth: Does firm size matter? The Journal of Finance, 6O(1), 137-177. Available at: https://doi.org/10.1111/j.1540-6261.2005.00727.x.

Beck, T., Demirgüç-Kunt, A., Laeven, L., \& Maksimovic, V. (2006). The determinants of financing obstacles. Journal of International Money and Finance, 25(6), 932-952.

Berhane, K. (2018). The role of financial development and institutional quality in economic growth in Africa in the Era of Globalization. In: Heshmati A. (eds) Determinants of Economic Growth in Africa: Palgrave Macmillan.

Blackburn, K., \& Forgues-Puccio, G. F. (2010). Financial liberalization, bureaucratic corruption and economic development. Journal of International Money and Finance, 29(7), 1321-1339. Available at: https://doi.org/10.1016/j.jimonfin.2010.05.002.

Blundell, R., \& Bond, S. (1998). Initial conditions and moment restrictions in dynamic panel data models. Journal of Econometrics, 87(1), 115-143. Available at: https://doi.org/10.1016/s0304-4076(98)00009-8.

Brunetti, A., Kisunko, G., \& Weder, B. (1999). Institutional obstacles to doing business: Region-by-region results from a worldwide survey of the private sector. World Bank Policy Research Working Paper No. 1759.

Caprio, G., Laeven, L., \& Levine, R. (2007). Governance and bank valuation. Journal of Financial Intermediation, 16(4), 584-617.

Casson, M. C., Giusta, M. D., \& Kambhampati, U. S. (2010). Formal and informal institutions and development. World Development, 38(2), 137-141 
Chinn, M. D., \& Ito, H. (2006). What matters for financial development? Capital controls, institutions, and interactions. Journal of Development Economics, 81(1), 163-192. Available at: https://doi.org/10.1016/j.jdeveco.2005.05.010.

Chossoudovsky, M. (2004). Globalization of poverty and the new world order. Montreal: Editions Ecosociété.

Chtourou, N. (2004). Institutional inefficiency and social performance. in (in) Restoration of the role of the state in economic development. Paris: Publisud Editions.

Claessens, S., Djankov, S., Fan, J. P., \& Lang, L. H. (2002). Disentangling the incentive and entrenchment effects of large shareholdings. The Journal of Finance, 57(6), 2741-2771. Available at: https://doi.org/10.1111/1540-6261.00511.

Claessens, S., \& Laeven, L. (2003). Financial development, property rights, and growth. The Journal of Finance, 58(6), $2401-2436$. Available at: https://doi.org/10.1046/j.1540-6261.2003.00610.x.

Coase, R. (1937). The nature of the firm. Economica 4(16), 386-405.

Demetriades, P., \& Andrianova, S. (2004). Finance and growth: What we know and what we need to know? in Goodhart, C. (Eds.) Financial Development and Economic Growth: Explaining the Links (pp. 38-65). Basingstoke and New York: Palgrave Macmillan.

Demetriades.., P., \& Hook-Law, S. (2006). Finance, institutions and economic development. International Journal of Finance E Economics, $11(3), 245-260$.

Djankov, S., McLiesh, C., \& Shleifer, A. (2007). Private credit in 129 countries. Journal of Financial Economics, 12(2), 77-99.

Hasan, I., Wachtel, P., \& Zhou, M. (2009). Institutional development, financial deepening andeconomic growth: Evidence from China. Journal of Banking and Finance, 33(1), 157-170. Available at: https://doi.org/10.1016/j.jbankfin.2007.1 1.016.

Holder, R. (2007). Institutions, trade and the political economy of financial development. Nncr Trade Regulation Swiss National Centre of Competence In Research Working Paper No 2007-27.

Hooper, V., Sim, A. B., \& Uppal, A. (2009). Governance and stock market performance. Economic Systems, 33(2), 93-116.

Kaidi, N., Mensi, S., \& Amor, M. B. (2019). Financial development, institutional quality and poverty reduction: Worldwide evidence. Social Indicators Research, 141(1), 131-156. Available at: https://doi.org/10.1007/s1 1205-018-1836-0.

Kaminsky, G. L., \& Schmukler, S. L. (2002). Emerging market instability: Do sovereign ratings affect country risk and stock returns? World Bank Economic Reviere, 16(2), 171-195.

Kaufmann, D., Kraay, A., \& Mastruzzi, M. (2008). Governance matters VII: Aggregate and individual governance indicators, 1996-2007. The World Bank Policy Research Working Paper No 4654.

Keefer, P., \& Knack, S. (1997). Why don't poor countries catch up? A cross-national test of institutional explanation. Economic Inquiry, 35(3), 590-602. Available at: https://doi.org/10.1111/j.1465-7295.1997.tbo2035.x.

Khan, M. A., Khan, M. A., Abdulahi, M. E., Liaqat, I., \& Shah, S. S. H. (2019). Institutional quality and financial development: The United States perspective. Journal of Multinational Financial Management, 49, 67-80. Available at: https://doi.org/10.1016/j.mulfin.2019.01.001.

Kunieda, T., Okada, K., \& Shibata, A. (2016). Corruption, financial development and economic growth: Theory and evidence from an instrumental variable approach with human genetic diversity. Economic Notes Review of Banking, Finance and Monetary Economics, 45(3), 353-392.

Kutan, A. M., Samargandi, N., \& Sohag, K. (2017). Does institutional quality matter for financial development and growth? Further evidence from MENA countries. Australian Economic Papers, 56(3), 228-248. Available at: https://doi.org/10.1111/1467-8454.12097.

LaPorta, R., Lopez-de-Silanes, F., Shleifer, A., \& Vishny, R. W. (1997). Legal determinants of external finance. Journal of Finance, 52(3), 1131-1150. Available at: https://doi.org/10.1111/j.1540-6261.1997.tb02727.x.

Law, S. H., \& Demetriades, P. (2006). Openness, institutions and financial development. World Economy \& Finance Research Programme Working Paper No. 0012.

Law, S. H., \& Habibullah, M. S. (2006). Financial development, institutional quality and economic performance in East Asian economies. Review of Applied Economics, 2(1076-2016-87141), 201-216. 
Law, S. H., \& Azman-Saini, W. N. W. (2008). The quality of institutions and financial development. University Library of Munich MPRA Paper No. 12107.

Law, S. H., \& Habibullah, M. S. (2009). The determinants of financial development: Institutions, openness and financial liberalisation. South African Journal of Economics, 77(1), 45-58. Available at: https://doi.org/10.1111/j.18136982.2009.01201.x.

Law, S. H., \& Azman-Saini, W. (2012). Institutional quality, governance, and financial development. Economics of Governance, 13(3), 217-236. Available at: https://doi.org/10.1007/s10101-012-0112-z.

Levine, R. (1997). Financial development and economic growth: Views and agenda. Journal of Economic Literature, 35(2), 688-726.

LLSV. (1997). Legal determinants of external finance. The Journal of Finance, 52(3), 1131-1150. Available at: https://doi.org/10.1111/j.1540-6261.1997.tb02727.x.

Lombardo, D., \& Pagano, M. (2000). Legal determinants of the return on equity. Stanford Law and Economics Olin Working Paper 193 and University of Salerno Working Paper No. 24

Mankiw, N. G., Romer, D., \& Weil, D. N. (1992). A contribution to the empirics of economic growth. The Quarterly Journal of Economics, 107(2), 407-437.

Martell, R., \& Stulz, R. M. (2003). Equity-market liberalizations as country IPO's. American Economic Reviere, 93(2), 97-101. Available at: https://doi.org/10.1257/000282803321946877.

Mersch, Y. (2005). Conditions for the success of capital account liberalization. Paper presented at the Meeting of French-Speaking Central Banks. May 9-12. Marrakech. Morocco.

Minea, A., \& Villieu, P. (2010). Financial development, institutional quality and maximizing-growth trade-off in government finance. Economic Modelling, 27(1), 324-335. Available at: https://doi.org/10.1016/j.econmod.2009.09.012.

Modigliani, F., \& Perotti, E. (2000). Security markets versus bank finance: Legal enforcement and investors' protection. International Review of Finance, 1(2), 81-96. Available at: https://doi.org/10.1111/1468-2443.00006.

North, D. C. (1990). Institutions, institutional change and economic performance. Cambridge: Cambridge University Press.

Pissarides, F., Singer, M., \& Svejnar, J. (2003). Objectives and constraints of entrepreneurs: Evidence from small and medium size enterprises in Russia and Bulgaria. Journal of Comparative Economics, 31(3), 503-531. Available at: https://doi.org/10.1016/s0147-5967(03)00054-4.

Pistor, K., Raiser, M., \& Gelfer, S. (2000). Law and finance in transition economies. Economics of Transition, 8(2), 325-368. Available at: https://doi.org/10.1111/1468-0351.00047.

Van Pottelsberghe De la Potterie, B. (1997). Issues in assessing the effect of interindustry R\&D spillovers. Economic Systems Research, 9(4), 331-356.

Wang, Y., Cheng, L., Wang, H., \& Li, L. (2014). Institutional quality, financial development and OFDI. Pacific Science Reviere, 16(2), 127-132. Available at: https://doi.org/10.1016/j.pscr.2014.08.023.

Weill, L. (2011). How corruption affects bank lending in Russia. Economic Systems, 35(2), 230-243. Available at: https://doi.org/10.1016/j.ecosys.2010.05.005.

Williamson, O. E. (1985). The economic institutions of capitalism: Firms, markets and relational contracting. New York: The Free Press.

Yartey, C. A. (2008). The determinants of stock market development in emerging economies: Is South Africa different? IMF Working Papers No. 08-32. 
Appendix 1. Variables and Sources.

\begin{tabular}{|c|c|c|}
\hline Variable & Notation & Source \\
\hline \multicolumn{3}{|l|}{ Dependent Variable } \\
\hline GDP per capita & Lny & World Development Indicators Online 2018 \\
\hline \multicolumn{3}{|l|}{ Basic Variables } \\
\hline Labor force & LnLF & World Development Indicators Online 2018 \\
\hline Accumulation of physical capital & Lnk & World Development Indicators Online 2018 \\
\hline Accumulation of human capital & Lnh & World Development Indicators Online 2018 \\
\hline \multicolumn{3}{|l|}{ Institutional Variables } \\
\hline \multicolumn{3}{|l|}{ ICRG } \\
\hline $\begin{array}{l}\text { * Corruption } \\
\text { * Laws and Orders } \\
\text { * Bureaucratic Quality } \\
\text { * Socioeconomic Conditions }\end{array}$ & \begin{tabular}{|l|} 
COR \\
LO \\
BQ \\
SEC \\
\end{tabular} & $\begin{array}{l}\text { International Country Risk Guide (ICRG): } 2018 \\
\text { www.prsgroup.com/icrg/ }\end{array}$ \\
\hline
\end{tabular}

Appendix 2. Descriptive Statistics.

\begin{tabular}{c|c|c|c|c|c|c|c}
\hline & Mean & Max. & Min. & Std. Dev. & Skewness & Kurtosis & Observations \\
\hline GDP & 8.701 & 9.708 & 7.987 & 0.453 & 0.399 & 1.988 & 126 \\
\hline $\operatorname{lnk}$ & 24.240 & 26.547 & 21.818 & 1.143 & 0.170 & 2.066 & 126 \\
\hline $\operatorname{lnh}$ & 4.186 & 4.542 & 3.570 & 0.293 & -0.744 & 2.168 & 116 \\
\hline Lnlf & -3.155 & -0.892 & -5.415 & 0.718 & -0.523 & 5.048 & 104 \\
\hline DCPS & 49.294 & 91.768 & 7.457 & 23.736 & -0.350 & 1.999 & 126 \\
\hline LL & 96.355 & 243.943 & 43.762 & 49.996 & 1.418 & 4.488 & 126 \\
\hline DCBS & 47.523 & 91.603 & 7.457 & 23.005 & -0.275 & 2.061 & 126 \\
\hline SEC & 5.421 & 7.000 & 1.000 & 1.022 & -1.040 & 5.752 & 126 \\
\hline COR & 2.566 & 4.000 & 1.000 & 0.897 & -0.098 & 2.194 & 126 \\
\hline LO & 4.221 & 6.000 & 1.000 & 1.011 & -0.819 & 3.854 & 126 \\
\hline BQ & 1.840 & 3.000 & 1.000 & 0.439 & -1.407 & 5.966 & 126 \\
\hline
\end{tabular}

Notes: GDP $=$ GDP per capita; $\mathrm{k}=$ accumulation of physical capital per capita; $\mathrm{h}=$ accumulation of human capital per capita; lf $=$ labor force; DCPS = domestic credit to private sector (\% of GDP), LL = liquid liabilities (M3) as \% of GDP; DCBS = domestic credit provided by banking sector (\% of GDP); $\mathrm{SEC}=$ socioeconomic conditions; $\mathrm{COR}=$ corruption; $\mathrm{LO}=$ law and order; $\mathrm{BQ}=$ bureaucracy quality.

Views and opinions expressed in this article are the views and opinions of the author(s), Asian Economic and Financial Review shall not be responsible or answerable for any loss, damage or liability etc. caused in relation to/arising out of the use of the content. 